\section{EDUCATION FOR MANAGEMENT REPORT ON A VISIT TO THE UNITED STATES}

$T$

HE Urwick Committee on Education for Manage-

ment, reporting in 1947, recommended the appointment of a small, but authoritative, commission to examine and report on existing facilities for management education in the Uniter States. More than twenty-five British productivity teams had, before the end of March 1951, almust unanimnusly attributed much of the drive for higher productivity per man-year, which they noted as characteristic of American business, to the attitude of the executives; and some teams traced a connexion between this attitude and a combination in the United States of facilities for higher educution and strict adlerence to promotion by merit. The Anglo-American Council on Productivity had already decided to send a number of teams dealing with educational problems, when the British Institute of Management suggested that yet another team should be sent to implement the recommendation of the Urwick Committee. This suggestion was accepted, and a report of the team's findings has now been published*

The team was under the leadership of Colonel L. F. Urwick and consisted of fourteen members made up of the followirg types of person : chairmen or managing directors of undertakings of various types and sizes; educationists, including a representative of the Ministry of Education, specially concerned with administrative studies; managers having direct responsibility for training; and a representative of the trade union movement, selected by the British Institute of Management after consultation with various bodies. Its terms of reference required this team "To secure some measure of the volume of effort devoted to formal education in management subjects in the United States at all levels; to visit selected educational establishments providing formal schemes of education and training for management, and to study their methods; to attempt to assess the acceptability of such formal education in management subjects to industry and commerce and its influence on the subsequent careers of students".

During its forty days in the United States, members of the team visited thirty universities and colleges, seven other institutions, eight trade unions and fifty industrial and commercial undertakings. Full details are given in an appendix, and much of the general interest of this comparatively brief report is derived from the sixty-six pages appended to the twenty pages of the main report. These appendixes include, for example, a representative list of some four hundred persons who gave competent and responsible opinion on education for administrution in discussion with members of the team; details of educational establishments in the United States which awarded degrees to students specializing in business or commerce in 1949-50; a glossary of American educational terms ; statistics of university students enrolled and degrees granted; declared objectives of the Massachusetts Institute of Technology and other institu. tions providing teaching in administrative studies; descriptions of the Harvard Graduate School of Business Administration and of some undergraduate and graduate courses in administrative studies, as

- Trodurtivity Report : Education for Management. Report of a Visit to the U.S.A. in 1951 of a Sperialist Team conrerned with on Productivity, 21 Tothill Street, London, S.W.1. 1951.) 48. 6 d. well as of courses for business executives and trade union officers, and of training schemes conducted by business. There are also collected extructs from reports of productivity teams which emphasize special characteristics of American managers that help productivity or which associate productivitymindedness among American executives with provision for the education and development of future executives. This factual material is clearly presented so as to illustrate the general impressions summarized in the report in successive chapters on the American educational picture ; education for business management; the schools of business administrution; business and education ; and executive development. Throughout, the report is admirably designed to serve the team's primary purpose of interpreting its experience in the United States in a manner which will help productivity in Britain.

The team believes that American experience has shown that productivity and education for management are closely related and that the whole question should be given further study in Britain. The findings of the team have been discussed in Nature of January 12 , p. 43 ; here it need only be added that the team was profoundly impressed by the volume and variety of educational effort devoted to administrative studies which has been developed in the United States within half a century and mostly within the past thirty years; by the vigour, enthu. siasm and sense of purpuse which have accompanied this growth; and by the intellectual modesty with which the architects and leaders of this experiment regard their own handiwork.

\section{PHYSIOLOGY OF MYXOMYCETES*}

\author{
BY Dr. LILIAN E. HAWKER \\ University of Bristol
}

$T$ HE study of Myxomycetes or Mycetozoa will always be associated with the name of Lister. The monograph on this group first published by Arthur Lister in $1894^{1}$ and afterwards revised by his daughter, the late Miss Gulielma Lister, is still the authority on the taxonomy and classification of these organisms and is a model of descriptive writing. The Listers, however, were also interested in the physiology of the slime moulds, including the effect of environment on spore germination, the feeding habits, the factors influencing formation of sporangia and the stimuli inducing and directing the amoboid movements of plasmodia and swarm cells. Their careful observations on these matters form the starting point for more recent work.

Observations on the factors influencing spore germination are scattered, incomplete and often contradictory. Nevertheless, it is clear that germination depends on both internal and external factors, as with germination of the spores of fungi. The degree of maturity of the spores is of importance. Many are unable to germinate immediately after formation, and, although they may remain viable for considerable periods, yet, in general, old spores germinate more slowly than young ones. Alternate wetting and drying was found by Lister to accelerate germination, and this has been confirmed by later

- Substance of the Iister Memorial Lecture delivered before the British Mycological Society on December 8, 1951. 